\title{
ANALISIS PEMBELAJARAN PENDIDIKAN JASMANI DI MASA PANDEMI COVID- 19 DI TINJAU DARI PENGGUNAAN MEDIA APLIKASI PEMBELAJARAN DAN USIA GURU
}

\author{
Maftukin Hudah ${ }^{1}$, Fajar Ari Widiyatmoko ${ }^{2}$, Galih Dwi Pradipta ${ }^{3}$, Osa Maliki ${ }^{4}$ \\ Email: maftukinhudah10@upgris.ac.id ${ }^{\mathbf{1}}, \underline{\text { fajarariwidiyatmoko@upgris.ac.id }}$, \\ Galihdwipradipta@upgris.ac.id ${ }^{3}$, osamaliki04@gmail.com ${ }^{4}$
}

1,2,3,4 Program Studi Pendidikan Jasmani Kesehatan dan Rekreasi Univeritas PGRI Semarang

\begin{abstract}
Abstrak
Tujuan penelitian ini adalah untuk mengetahui bagaimana proses pembelajaran pendidikan jasmani di masa pandemi Covid-19 di tinjau dari penggunaan media aplikasi pembelajaran dan usia guru di Kab. Demak. Desain penelitian ini adalah ex-post facto (kausal komparatif) untuk melihat bagaimana media dan kegiatan pembelajaran yang dilakukan oleh guru pendidikan jasamani di masa pendemi Covid-19. Intrument penelitian menggunakan angket daring dengan beberapa pertanyaan, mulai dari data diri guru meliputi nama, jenis kelamin, jenjang sekolah, media yang digunakan, kendala atau hambatan yang dialami serta kesan dan persepsi terhadap pembelajaran daring. Sampel dalam penelitian ini adalah guru penjas dari jenjang sekolah dasar sampai menengah. Hasil penelitian presentase $20.0 \%$ sedangkan usia 40 Tahun ke atas $23.0 \%$. Beberapa aplikasi yang dapat dimanfaatkan untuk pembelajaran daring, antara lain: whatsapp, facebook, telegram, google classroom, dan google formulir. Berdasarkan paparan di atas maka dapat disimpulkan bahwa guru di Kabupaten Demak dalam proses pembelajaran daring selama covid-19 berdasarakan penggunaan aplikasi media dan usia terdapat pada guru sekolah dasar pengunaan aplikasi Whatsapp Guru SD uisa 20-40 tahun presentase $35.0 \%$ sedangkan usia 40 Tahun ke atas 39.0\%. Aplikasi whatsaap di anggap paling mudah untuk proses pembelajaran yang langsung bisa di akses dan mudah.
\end{abstract}

Kata Kunci: Analisis Pembelajaran Pendidikan Jasmani, Media Aplikasi Pembelajaran Dan Usia Guru Di Kab. Demak

\section{Abstract}

The purpose of this study was to find out how the physical education learning process during the Covid-19 pandemic was reviewed from the use of learning application media and the age of teachers in Kab. Demak. The design of this research is ex-post facto (causal comparative) to see how the media and learning activities carried out by physical education teachers during the Covid-19 epidemic. The research instrument used an online questionnaire with several questions, starting from the teacher's personal data including name, gender, school level, the media used, the obstacles or obstacles experienced as well as impressions and perceptions of online learning. The sample in this study were physical education teachers from elementary to middle school levels. The results of the study were the percentage of $20.0 \%$ while those aged 40 years and over 23.0\%. Some applications that can be used for online learning include: whatsapp, facebook, telegram, google classroom, and google forms. Based on the explanation 
above, it can be concluded that teachers in Demak Regency in the online learning process during covid 19 based on the use of media applications and age were found in elementary school teachers using the Whatsapp application, SD teachers, uisa 20-40 years old, the percentage was $35.0 \%$ while those aged 40 years and over $39.0 \%$. The whatsaap application is considered the easiest for the learning process that is immediately accessible and easy.

Keywords: Physical Education Learning Analysis, Learning Application Media and Teacher Age In Kab. Demak

\section{A. Pendahuluan}

Pandemi Covid-19 yang muncul desember 2019 lalu berdampak terhadap semua bidang, tidak terkecuali bidang pendidikan. Segala kegiatan di dalam dan di luar ruangan disemua sektor sementara waktu ditunda demi mengurangi penyebaran Covid-19, sehingga sekolah-sekolah di sejumlah wilayah di Indonesia sampai saat ini masih menggunakan media daring. Kemendikbud mengeluarkan Surat Edaran Nomor 4 Tahun 2020 Tentang Pelaksanaan Kebijakan Pendidikan Dalam Masa Darurat Penyebaran covid, yang menyebutkan bahwa proses belajar dilaksanakan di rumah melalui pembelajaran daring/jarak jauh. Saat alternatif bentuk pembelajaran yang bisa dilakukan selama ini darurat Covid-19 adalah pembelajaran online. Menurut Moore, DicksonDeane, \& Galyen (2011) pembelajaran online adalah pembelajaran yang menggunakan jaringan internet dengan aksesibilitas, konektivitas, fleksibilitas, dan kemampuan untuk memunculkan berbagai jenis interaksi pembelajaran. Dalam hal ini Kemendikbud memberikan kebebasan bagi tiap sekolah untuk memilih platform belajar daring mereka. Akan tetapi, untuk mendorong adanya proses berbagi pengetahuan, Kemendikbud menyediakan platform belajar daring gratis bernama "Rumah Belajar" dan sebuah platform untuk berbagi antar guru yang bernama "Program Guru Berbagi". "Rumah Belajar" menyediakan bahan mengajar dan fitur komunikasi untuk para penggunanya, sementara "Program Guru Berbagi" berbagi Rencana Pelaksanaan Pembelajaran (RPP) dengan guru-guru di seluruh Indonesia (Kemendikbud 2020). Untuk daerah dengan koneksi internetnya tidak terlalu baik, pemerintah bekerja sama dengan TVRI, stasiun televisi negara, untuk menyampaikan materi belajar yang ada di dalam program Belajar di Rumah untuk beberapa bulan (Beritasatu, 2020).

Teknologi, lebih spesifiknya internet, smartphone, dan laptop sekarang digunakan secara luas untuk mendukung pembelajaran jarak jauh. Salah satu penyedia jasa telekomunikasi terbesar di Indonesia mencatat peningkatan arus broadband sebesar 16\% selama krisis Covid-19, yang disebabkan oleh tajamnya peningkatan penggunaan platform pembelajaran jarak jauh (Azzahra, 2020). Topografi Indonesia yang berupa kepulauan dan pegunungan membutuhkan pengadaan internet dan telekomunikasi seluler yang merata. Kenyataannya jangkauan 4G kebanyakan terkonsentrasi di Pulau Jawa karena penyedia layanan telekomunikasi seluler, yang sangat bergantung pada pasar, tentu saja memprioritaskan daerah-daerah perkotaan dibandingkan daerah pedesaan yang populasinya lebih sedikit (Khatri, 2019). Perubahan mendadak dari metode tatap muka di ruang kelas menjadi pembelajaran jarak jauh di rumah, selain hambatan datang dari siswa yang sulit untuk mengakses jaringan internet (Azzahra, 2020; Mufarikhah 2020), juga menunjukkan kebutuhan peningkatan kapasitas guru dalam menggunakan media Rigianti, H. A. (2020) bahkan sampai pada tahap asesmen pembelajaran (Iqbal 2020). Kompetensi informasi, komunikasi, dan teknologi (ICT) guru Indonesia tidak tersebar merata di 
seluruh wilayah (Koh et al, 2018). Terlebih lagi, ada kesenjangan kualitas pendidikan di seluruh wilayah di Indonesia, terutama antara Jawa dan luar Jawa, dan di antara kondisi-kondisi sosioekonomi (Azzizah, 2015; Muttaqin 2018). Akses internet yang tidak merata, kesenjangan kualifikasi guru, dan kualitas pendidikan, serta kurangnya keterampilan ICT menjadi kerentanan dalam inisiatif pembelajaran jarak jauh di Indonesia. Dari sekian banyak masalah diatas nampaknya demikian juga yang terjadi pada pembelajaran pendidikan jasmani. Terlebih pendidikan jasmani menggunakan media aktivitas fisik dalam pembelajarannya (Suherman, (2009). Oleh karena itu penelitian ini dilakukan. Penelitian ini bertujuan untuk mencari informasi bagaimana desain pembelajaran pendidikan jasamni yang dilakukan di sekolah pada masa pandemi, mulai dari media yang digunakan, materi dan hambatan yang dialami dalam pembelajaran daring.

\section{B. Metode}

Data dari survei selanjutnya akan dimasukkan ke dalam MS Excel spreadsheet dan telah disusun. Pertanyaan yang bersifat kuantitatif akan disajikan dalam statistik umum. Untuk data yang bersifat kualitatif; akan dianalisa menggunakan kode terbuka dan kemudian dengan kode aksial untuk mengkategorikan dan mensintesis tema yang muncul (Creswell, 2007). Desain penelitian ini adalah ex-post facto (kausal komparatif) untuk melihat bagaimana media dan kegiatan pembelajaran yang dilakukan oleh guru pendidikan jasamani di masa pendemi covid19. Intrument penelitian menggunakan angket daring dengan beberapa pertanyaan, mulai dari data diri guru meliputi nama, jenis kelamin, jenjang sekolah, usia, media yang digunakan dalam pembelajaran daring. Sampel dalam penelitian ini adalah guru penjas dari jenjang sekolah dasar sampai menengah.

\section{Hasil dan Pembahasan}

Berdasarkan paparan di atas maka dapat disimpulkan bahwa guru di Kabupaten Demak dalam proses pembelajaran Daring selama covid 19 berdasarakan penggunaan aplikasi media dan usia terdapat pada guru sekolah dasar pengunaan aplikasi Whatsapp Guru SD uisa 20-40 tahun presentase $35.0 \%$ sedangkan usia 40 Tahun ke atas $39.0 \%$. Aplikasi whatsaap di anggap paling mudah untuk proses pembelajaran yang langsung bisa di akses dan mudah. Tujuan Penelitian ini adalah untuk mengetahui Bagaimana proses pembelajaran Pendidikan jasmani di masa Pandemi Covid-19 di tinjau dari media pembelajaran dan usia. Populasi dalam penelitian ini adalah Guru Sekolah Dasar (SD) dengan 40 Responden, Sekolah Menengah Pertama (SMP) dengan 28 Responden, dan Sekolah Menengah Atas (SMA) dengan 26 Responden sehingga total 98 responden Guru di Kabupaten Demak. Teknik Pengumpulan data yang di gunakan wawancara, kuisioner dan dokumentasi. Penelitian ini dilaksanakan pada bulan Agustus sampai dengan bulan Oktober 2020. Berikut adalah data dan analisis yang diperoleh melalui angket dari Hasil analisis pembelajaran Penjasorkes di masa pandemic covid -19 sebagai berikut: 
Tabel 1. Deskriptif Usia Guru SD, SMP dan SMA Di Kabupaten Demak

\begin{tabular}{cccc} 
Jenjang Mengajar & Usia & Frekuensi & Persentase (\%) \\
\hline SD & $20-40$ th & 23 & $23.47 \%$ \\
& $>40$ th & 21 & $21.43 \%$ \\
SMP & $20-40$ th & 20 & $20.41 \%$ \\
& $>40$ th & 8 & $8.16 \%$ \\
\multirow{2}{*}{ SMA } & $20-40$ th & 24 & $24.49 \%$ \\
& $>40$ th & 2 & $2.04 \%$ \\
\hline & Jumlah & & 98
\end{tabular}

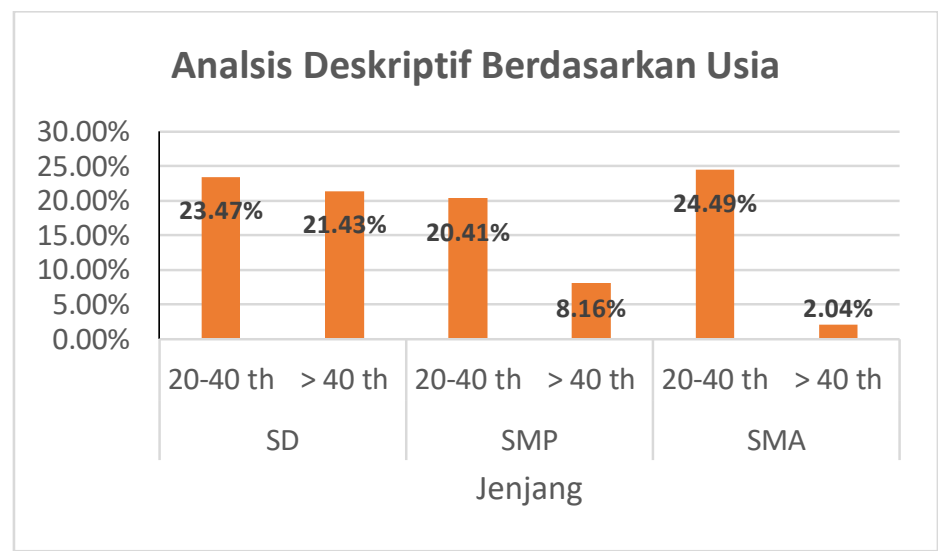

Diagram 1. Berdasarkan Usia Guru

Berdasarkan diagram di atas dapat di ketahui bahwa presentase untuk usia Guru Sekolah Dasar (SD), paling rendah adalah usia 40 Tahun keatas dengan prosentase $(21.43 \%$ ) sedangkan rentang usia 20-40 tahun dengan prosentase 23.47\%, untuk usia Guru Sekolah Menengah Pertma (SMP), paling rendah adalah 40 Tahun keatas 8.16\% sedangkan usia 20-40 tahun dengan prosentase 20,40\%, sedangkan usia Guru Sekolah Menengah Atas (SMA) paling rendah adalah usia 40 Tahun keatas dengan prosentase 2.04\%, sedangkan usia 20-40 tahun dengan prosentase $24.49 \%$, ini berarti uisa Guru di kabupaten Demak dengan kategori tinggi di bawah usia 20-40 tahun hal ini merupakan transisi dimana tantangan dan update dalam pembelajaran menjadi tantangan baru bagi usia produktif. Di masa Pandemi Covid 19 ini tentunya setiap Guru di tantang untuk selalu mengikuti perkembangan teknologi dan solusi yang inovatif serta tidak membuat siswa saat belajar daring menemui kesulitan untuk mendapatkan fasilitas yang di lakukan oleh Guru ke siswa, berdasrkan hasil angket di atas peneliti melakukan analisis kesiapan sekolah, guru dan siswa dalam melaksanakan pembelajaran daring selama pandemic covid 19. Berikut adalah analisis angket Aplikasi Media pembelajaran yang di gunakan Guru di Kabupaten Demak. 


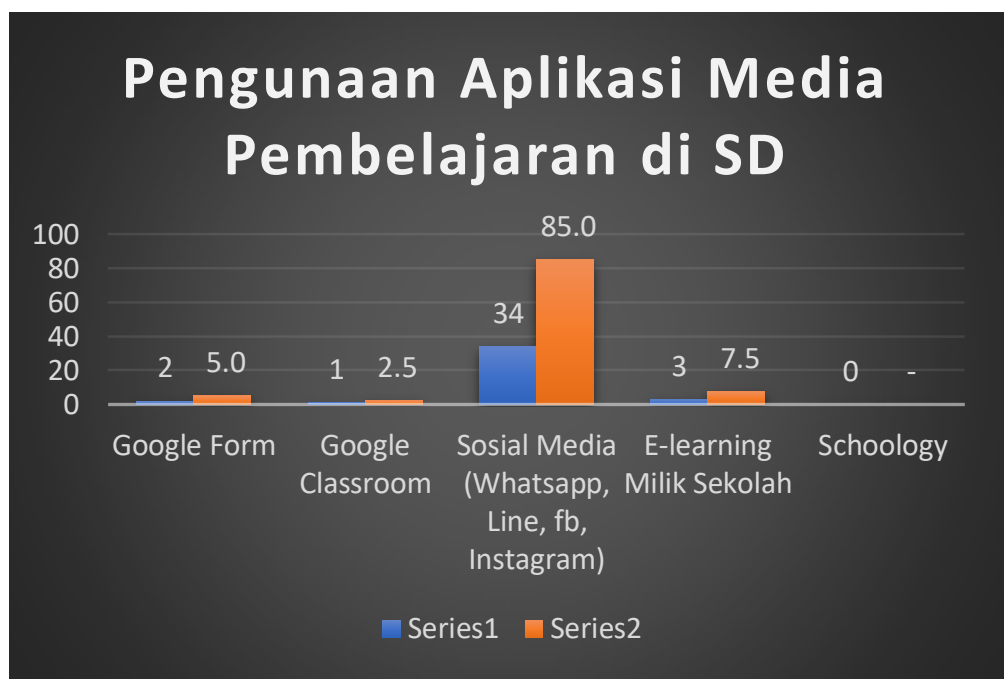

Diagram 2. Penggunaan Aplikasi Media pembelajaran di SD

Berdasarkan diagram diatas terdapat 5\% guru yang menggunakan aplikasi Google Form, 2.5\% menggunakan google Classroom, $85.0 \%$ menggunakan media aplikasi Wahatsapp sedangkan $7.5 \%$ aplikasi E-Lerning dari sekolah. Informasi ini di dapat melalui angket yang di isi oleh setiap guru di Sekola Dasar (SD). Jadi bisa di Tarik kesimpulan untuk Guru SMP penggunaan media aplikasi yang di gunakan dengan prosentasi tertinggi adalah menggunakan Sosial Media Whatsapp sebesar 85.0\%.

\section{Pengunaan Aplikasi Media Pembelajaran di SMP}

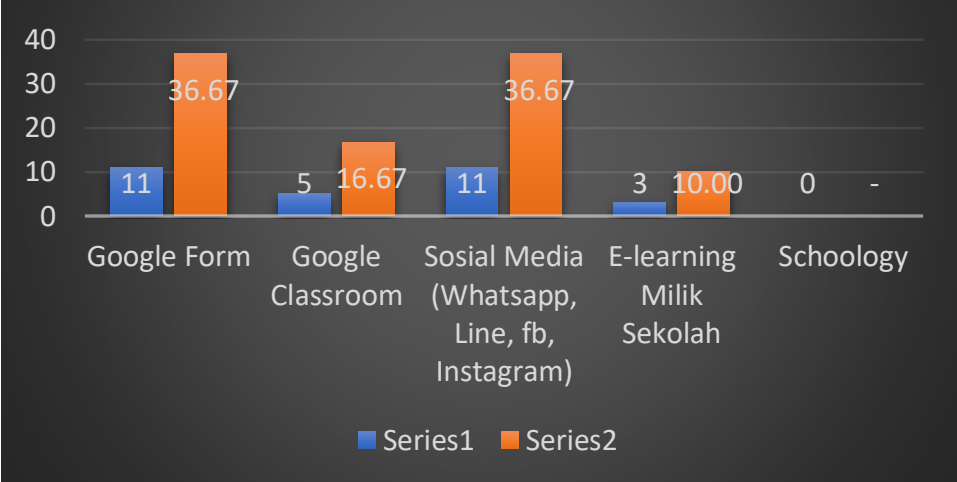

Diagram 3. Penggunaan Aplikasi Media pembelajaran di SMP

Berdasarkan diagram di atas terdapat 36,67\% penggunaan Google form, 16,67\% Google Clasroom, 36.67\% menggunakan Sosial Media Whatsapp dan 10\% E-learning Milik Sekolah. Jadi bisa di Tarik kesimpulan untuk Guru SMP penggunaan media aplikasi yang di gunakan dengan prosentasi tertinggi adalah menggunakan Sosial Media Whatsapp sebesar 36.67\%. 


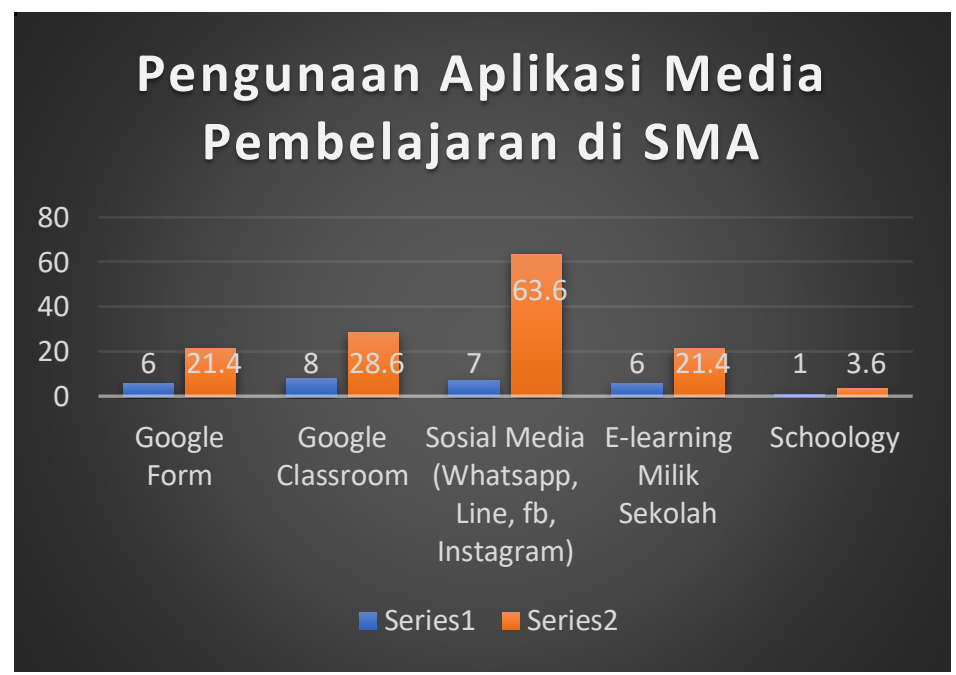

Diagram 4. Penggunaan Aplikasi Media pembelajaran di SMA

Berdasarkan diagram di atas terdapat $21.4 \%$ penggunaan Google form, $28.6 \%$ Google Clasroom, 63.6\% menggunakan Sosial Media Whatsapp, 21.4\% E-learning Milik Sekolah dan 3.6\% schoology. Jadi bisa di Tarik kesimpulan untuk Guru SMP penggunaan media aplikasi yang di gunakan dengan prosentasi tertinggi adalah menggunakan Sosial Media Whatsapp sebesar $63.6 \%$. Dalam proses pembelajaran daring, guru memiliki batas kemampuan untuk menggunakan aplikasi yang di gunakan kepada siswa baik secara sarana dan prasarana yang di miliki masing-masing sekolah, Guru, siswa dan letak geografis mempengaruhi kebermanfaatan media tersebut, oleh sebab itu dalam data penelitian dilapangan berdasarkan sebaran usia dan penggunakan aplikasi media dalam pembelajaran daring maka di dapat data sebagai berikut:

\section{PENGGUNAAN APLIKASI MEDIA PEMBELAJARAN DAN USIA GURU SD}

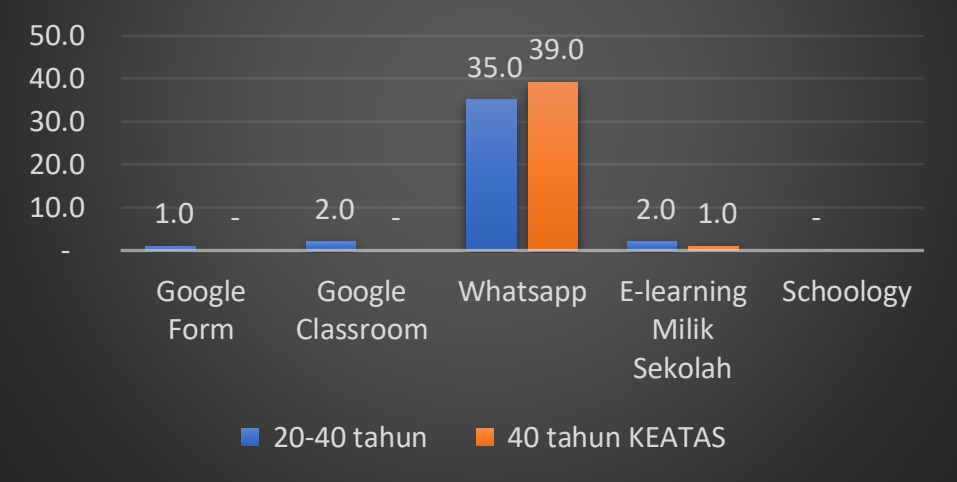

Diagram 5. penggunaan Aplikasi Media pembelajaran dan usia Guru SD 
Berdasarkan data diatas di usia 20-40 tahun untuk guru sekolah dasar yang menggunakan media aplikasi google form sebesar $1 \%$ sedangkan usia 40 tahun ke atas $0 \%$ dengan kategori kurang, usia 20-40 tahun untuk guru sekolah dasar yang menggunakan media google classroom 2\% sedangkan usia 40 tahun ke atas 0\% dengan kategori kurang, 20-40 tahun untuk guru sekolah dasar yang menggunakan media aplikasi Sosial Media Whatsapp sebesar 35\% sedangkan usia 40 tahun ke atas 39\% dengan kategori tinggi, usia 20-40 tahun untuk guru sekolah dasar yang menggunakan media aplikasi E-Leraning sebesar 2\% sedangkan usia 40 tahun ke atas 1\% dengan kategori kurang, untuk schoology tidak di gunakan, maka dapat di Tarik kesimpulan untuk Guru SD di Kab. Demak 20-40 tahun untuk guru sekolah dasar yang menggunakan media aplikasi Sosial Media Whatsapp sebesar 35\% sedangkan usia 40 tahun ke atas $39 \%$ dengan kategori tinggi.

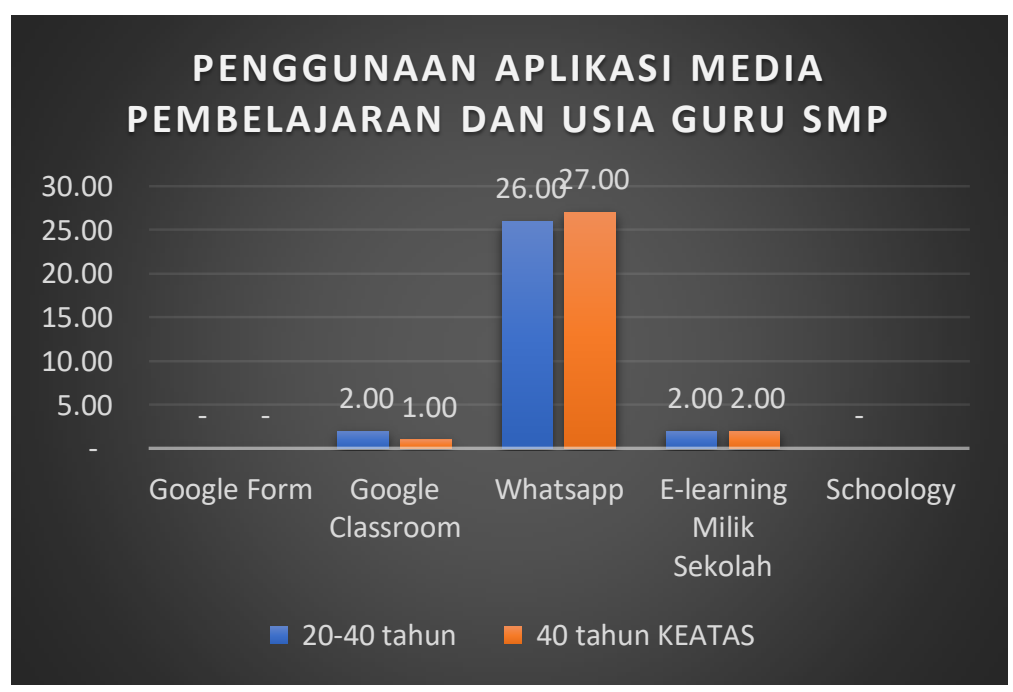

Diagram 6. Penggunaan Aplikasi Media pembelajaran dan usia Guru SMP

Berdasarkan data diatas di usia 20-40 tahun untuk guru SMP yang menggunakan media aplikasi google form sebesar $0 \%$ sedangkan usia 40 tahun ke atas $0 \%$ dengan kategori kurang, usia 20-40 tahun untuk guru SMP yang menggunakan media google classroom 2\% sedangkan usia 40 tahun ke atas 1\% dengan kategori kurang, 20-40 tahun untuk guru SMP yang menggunakan media aplikasi Sosial Media Whatsapp sebesar 26\% sedangkan usia 40 tahun ke atas 27\% dengan kategori tinggi, usia 20-40 tahun untuk guru SMP yang menggunakan media aplikasi E-Leraning sebesar 2\% sedangkan usia 40 tahun ke atas 2\% dengan kategori kurang, untuk schoology tidak di gunakan, maka dapat di tarik kesimpulan untuk guru SMP di Kab. Demak 20-40 tahun untuk guru sekolah dasar yang menggunakan media aplikasi Sosial Media Whatsapp sebesar 26\% sedangkan usia 40 tahun ke atas $27 \%$ dengan kategori tinggi. 


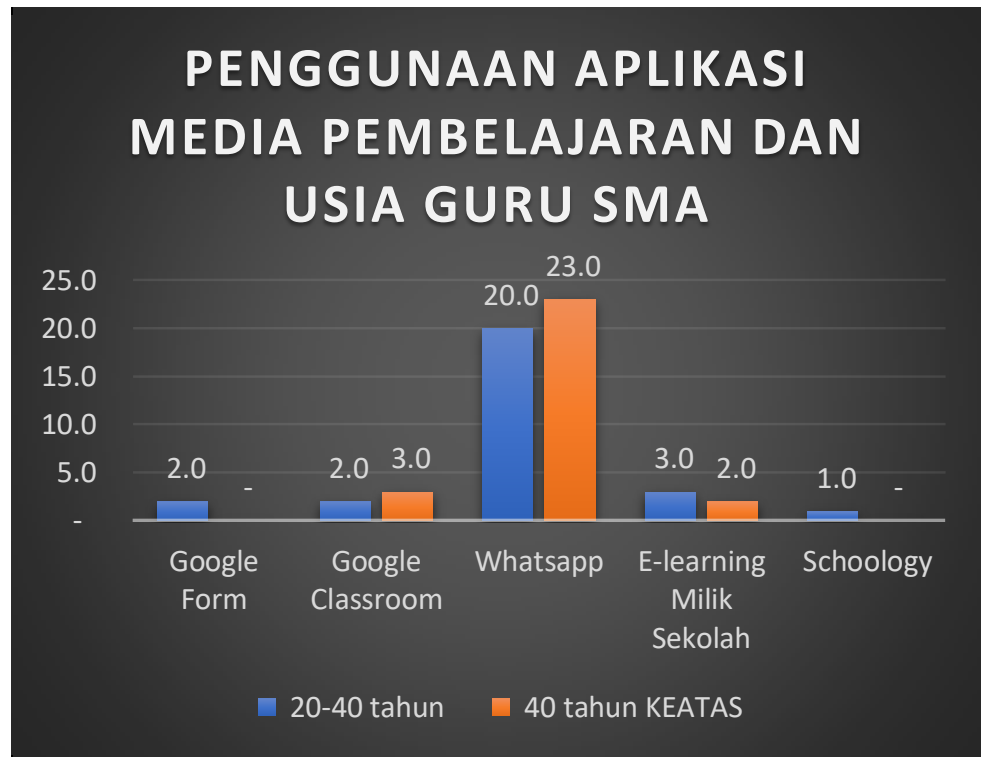

Diagram: 7. Penggunaan Aplikasi Media pembelajaran dan usia Guru SMA

Berdasarkan data diatas di usia 20-40 tahun untuk Guru SMA yang menggunakan media aplikasi google form sebesar 2\% sedangkan usia 40 tahun ke atas $0 \%$ dengan kategori kurang, usia 20-40 tahun untuk Guru SMA yang menggunakan media google classroom 2\% sedangkan usia 40 tahun ke atas 3\% dengan kategori kurang, 20-40 tahun untuk guru SMP yang menggunakan media aplikasi Sosial Media Whatsapp sebesar $20 \%$ sedangkan usia 40 tahun ke atas 23\% dengan kategori tinggi, usia 20-40 tahun untuk guru SMP yang menggunakan media aplikasi E-Leraning sebesar 3\% sedangkan usia 40 tahun ke atas 2\% dengan kategori kurang, untuk usia 20-40 tahun untuk guru SMP yang menggunakan media aplikasi schoology sebesar $1 \%$ sedangkan usia 40 tahun ke atas $0 \%$, maka dapat di tarik kesimpulan untuk guru SMA di Kab. Demak 20-40 tahun untuk guru sekolah dasar yang menggunakan media aplikasi Sosial Media Whatsapp sebesar 20\% sedangkan usia 40 tahun ke atas $23 \%$ dengan kategori tinggi. Berdasarkan hasil diatas dapat ditarik kesimpulan bahwa pembelajaran daring yang dilakukan oleh Guru se Kab.Demak dengan jenjang sekolah dasar sampai menengah atas aplikasi media dan usia guru bahwa aplikasi aplikasi sosial media Whatsapp yang paling banyak di gunakan oleh guru dengan presentase sebagai berikut:

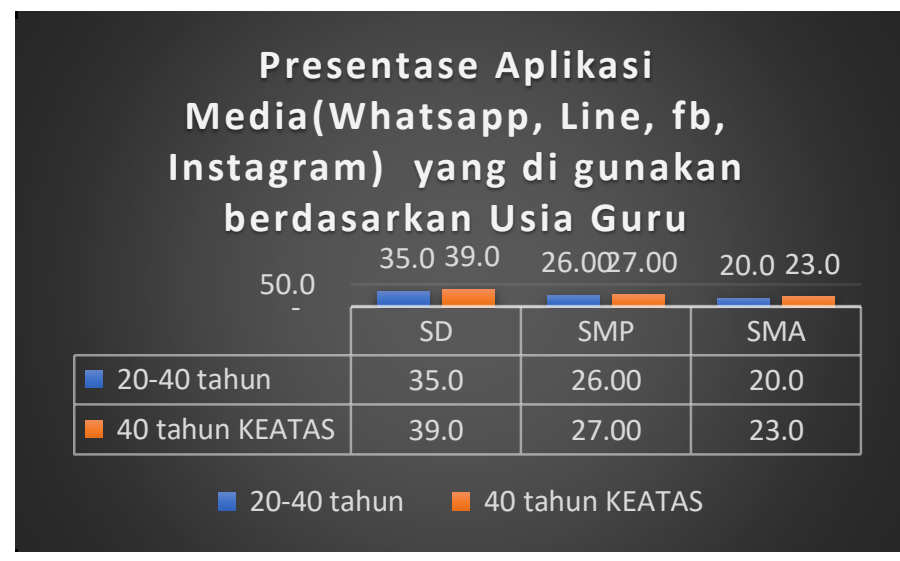

Journal Pendidikan Jasmani Kesehatan \& Rekreasi (PORKES) |100 
Berdasarkan diagram di atas dalam pengunaan aplikasi Whatsapp Guru SD uisa 20-40 tahun presentase 35.0\% sedangkan usia 40 Tahun ke atas 39.0 \%, Guru SMP uisa 20-40 tahun presentase $26.0 \%$ sedangkan usia 40 Tahun ke atas 27.0\%, Guru SMA uisa 20-40 tahun presentase $20.0 \%$ sedangkan usia 40 Tahun ke atas 23.0\%. Maka kita dapat menarik kesimpulan dalam keefektifan pengunaan aplikasi media selama pandemic covid untuk pembelajaran penjas yang di gunakan oleh guru untuk Daring "Belajar di rumah", kini merupakan satu isilah yang tidak lagi asing didengar walaupun istilah ini sepertinya belum pernah terpikirkan sebelumnya. Selama ini banyak pihak yang menganggap bahwa kegiatan belajar di rumah tidak efektif, namun di tengah-tengah situasi mewabahnya virus corona, seolah-olah semua melupakan seluruh kekhawatiran akan ketidak-efektifan tersebut. beberapa aplikasi yang dapat dimanfaatkan untuk pembelajaran daring, antara lain: whatsapp, facebook, telegram, googleclassroom, dan google formulir. penggunaan whatsapp karena merupakan aplikasi yang paling banyak dimiliki dan digunakan sehari-hari oleh sebagian besar guru di Kabupaten Demak ,guru dapat menyampaikan materi pembelajaran dan penugasan bagi peserta didiknya.

\section{Simpulan}

Berdasarkan hasil penelitian diatas kita dapat menyimpulkan bahwa untuk mempersiapkan generasi yang siap dalam kompetensi dan kompetisi zaman yang selalu berkembang kita harus selalu update dan tidak tergantung pada keadaan. Tentunya sebagai guru harus tanggap dalam teknologi dan pengembangan diri untuk menciptakan suasana akademik yang aktif, kreatif, humanis dan solutif

\section{Daftar Pustaka}

Azzahra, N. F. (2020). Mengkaji Hambatan Pembelajaran Jarak Jauh di Indonesia di Masa Pandemi Covid-19.

Azzizah, Y. (2015). Socio-Economic Factors on Indonesia Education Disparity. International Education Studies. 8(12). 218-230

Ahmad, I. F. (2020). Asesmen alternatif dalam pembelajaran jarak jauh pada masa darurat penyebaran coronavirus disease (covid-19) di Indonesia. Pedagogik: Jurnal Pendidikan, 7(1), 195-222.

Asnawir, B. U., \& Usman, M. B. (2002). Media pembelajaran. Jakarta: Ciputat Pers.

Beritasatu. (2020). Education Ministry Teams Up with TVRI to Deliver Distance Learning. Jakarta Globe. Diambil dari: https:// jakartaglobe.id/news/education-ministry-teams-upwith-tvri-to-deliver-distance-learning

Creswell, J. W. (2007). Five qualitative approaches to inquiry. Qualitative inquiry and research design: Choosing among five approaches, 2, 53-80.

Dede, C. (1996). The evolution of distance education: Emerging technologies and distributed learning. The American Journal of Distance Education, 10 (2), 4-36.

Dewi, W. A. F. (2020). Dampak Covid-19 terhadap implementasi pembelajaran daring di Sekolah Dasar. Edukatif: Jurnal Ilmu Pendidikan, 2(1), 55-61.

Kemendikbud (2020). Belajar dari Rumah, Satuan Pendidikan Dapat Pilih Platform Pembelajaran Jarak Jauh. Ministry of Education and Culture. Diambil dari: 
https://www.kemdikbud.go.id/main/blog/2020/04/belajar-dari-rumahsatuan-pendidikandapat-pilih-platform-pembelajaran-jarak-jauh-sesuai-kebutuhan

Khatri, H. (2019). Indonesian users in sparsely-populated urban areas connect to 4G more than $70 \%$ of the time. Opensignal. Diambil dari: https://www.opensignal.com/2019/11/12/indonesian-users-in-sparsely-populated-ruralareas-connect-to4g-more-than-70-of-the-time

Koh, J. H. L., Chai, C. S., \& Natarajan, U. (2018). Developing Indonesia teachers' technological pedagogical content knowledge for 21st century learning (TPACK-21CL) through a multi-prong approach. Journal of International Education and Business, 3(1), 11-33.

Lowenthal, P., \& Wilson, B. G. (2010). Labels do matter! A critique of AECT's redefinition of the field. TechTrends, 54(1), 38-46, doi:10.1007/s11528-009-0362-y

Mahnun, N. (2012). Media pembelajaran (kajian terhadap langkah-langkah pemilihan media dan implementasinya dalam pembelajaran). An-Nida', 37(1), 27-34.

Moore, J. L., Dickson-Deane, C., \& Galyen, K. (2011). e-Learning, online learning, and distance learning environments: Are they the same?. The Internet and Higher Education, 14(2), 129-135.

Mufarikhah umar, L. U. L. U. S., \& Nursalim, M. (2020). Studi kepustakaan tentang dampak wabah covid-19 terhadap kegiatan belajar mengajar pada siswa sekolah dasar (SD). Jurnal BK UNESA, 11(4).

Muttaqin, T. (2018). Determinants of Unequal Access to and Quality of Education in Indonesia. The Indonesian Journal of Development Planning. 2(1). 1-20.

Rigianti, H. A. (2020). Kendala Pembelajaran Daring Guru Sekolah Dasar Di Banjarnegara. Elementary School: Jurnal Pendidikan dan Pembelajaran ke-SD-an, 7(2).

Suherman, A. (2009). Revitalisasi pengajaran dalam pendidikan jasmani. Bandung: CV. Bintang Warli Artika. 